\title{
A pterodactyloid pterosaur from the Upper Cretaceous Lapurr sandstone, West Turkana, Kenya
}

\author{
PATRICK M. O'CONNOR ${ }^{1,2}$, JOSEPH J.W. SERTICH ${ }^{3}$ and FREDRICK K. MANTHI ${ }^{4}$ \\ ${ }^{1}$ Department of Biomedical Sciences, Ohio University College of Osteopathic Medicine, Athens, OH 45701, USA \\ ${ }^{2}$ Ohio Center for Ecology and Evolutionary Studies, Irvine Hall, Ohio University, Athens, OH 45701, USA \\ ${ }^{3}$ Department of Anatomical Sciences, Health Sciences Center T8-040, Stony Brook University, Stony Brook NY 11794, USA \\ ${ }^{4}$ Department of Earth Sciences, National Museums of Kenya, P.O. Box 40658-00100, Nairobi, 00100 Kenya \\ Manuscript received on January 15, 2010; accepted for publication on December 1, 2010
}

\begin{abstract}
An isolated pterosaurian caudal cervical ( postcervical) vertebra was recovered from the Upper Cretaceous Lapurr sandstone of West Turkana, northwestern Kenya. The vertebral centrum is short, wide, and dorsoventrally compressed. Although the specimen is lightly built similar to most pterosaurs, it is here referred to Pterodactyloidea and tentatively to the Azhdarchidae in that it lacks pneumatic features on both the centrum and neural arch. This represents one of the few pterosaurs recovered from the entirety of Afro-Arabia, the first pterosaur recovered from the Cretaceous of East Africa, and, significantly, a specimen that was recovered from fluvial deposits rather than the near-shore marine setting typical of most pterosaur discoveries.
\end{abstract}

Key words: Pterosauria, Pterodactyloidea, Africa, Kenya, Late Cretaceous.

\section{INTRODUCTION}

Upper Cretaceous terrestrial/freshwater deposits from continental Africa are rare (Haughton 1963, Dingle et al. 1983, Mateer et al. 1992) and limited to a handful of geographically-restricted sites. Despite this paucity of terrestrial sequences, a number of paleobiogeographic hypotheses have been proposed to account for the distribution of terrestrial vertebrate groups (e.g., dinosaurs) on former Gondwanan landmasses during the Late Cretaceous ( $\sim 100$ to 65 mya) (see Krause et al. 2006 for a recent summary). This period is of significance in that it coincides with the most active fragmentation of the Gondwanan supercontinent (Scotese 2001), an event that likely influenced the evolution and spatial distribution of resident biotas through speciation, dispersal, and extinction events. O'Connor et al. (2006) discussed limitations for conducting supercontinent-level paleobiogeographic

Proceedings of the Third Gondwanan Dinosaur Symposium Correspondence to: Patrick M. O'Connor

E-mail: oconnorp@ohiou.edu analysis in the face of an abundance of missing data, framing the most obvious deficiency for Gondwananwide inferences as the 'African Gap' during the Late Cretaceous Period.

Within this general context then, it is not surprising that the fossil record of the lightly-built pterosaurs from Afro-Arabia is limited to a handful of mostly isolated skeletal and dental remains (e.g., Reck 1931, Swinton 1948, Galton 1980, Monteillet et al. 1982, SigogneauRussell et al. 1998, Unwin and Heinrich 1999, Mader and Kellner 1999, Wellnhofer and Buffetaut 1999, Benton et al. 2000, Barrett et al. 2008, Costa and Kellner 2009). Exceptions to these isolated discoveries include (1) the Maastrichtian azhdarchid Phosphatodraco, consisting of a semi-articulated series of five cervical vertebrae recovered from the Oulad Abdoun Phosphatic Basin in Morocco (Pereda Suberbiola et al. 2003; also see Kellner 2010) and (2) a partial pteranodontoid forelimb from the Cenomanian Hâqel Lagerstätte in Lebanon (Dalla Vecchia et al. 2001). 
Recent field research in the Lapurr sandstone [Turkana Grits] in West Turkana, northwestern Kenya (Fig. 1), has yielded a number of new Late Cretaceous vertebrates (Sertich et al. 2005, 2006). Included among the archosaurs are multiple saurischian dinosaurs, crocodyliforms, and the pterosaur vertebra detailed in this report. This represents the first pterosaur reported from the Late Cretaceous of East Africa and one of the few pterosaurs from the continent recovered from a fluvial depositional system.

Pterosauria Kaup 1834

Pterodactyloidea Plieninger 1901

?Azhdarchidae Nesov 1984

Material - KNM-WT (Kenya National Museum, West Turkana) 47893 is a heavily-abraded, isolated caudal cervical vertebra (Fig. 2).

Locality and horizon - The specimen described herein was recovered from the Lapurr sandstone, "Turkana Grits" (Upper Cretaceous) exposed in the Lapurr Range on the west side of Lake Turkana, northwestern Kenya (Fig. 1). The Lapurr sandstone is a succession of fine to coarse arkosic sandstones of indeterminate age resting noncomformably over Precambrian metamorphic basement and overlain by Oligocene basalts. Fluvial deposition of the Lapurr sandstone is likely related to the development of the Cenomanian-Paleogene Anza Rift system (Bosworth and Morley 1994, Morley et al. 1999, Tiercelin et al. 2004), though reliable age estimates of the series remain elusive. An estimate of Upper Cretaceous (Turonian-early Campanian) is based on comparisons with subsurface geological information (Winn et al. 1993, Bosworth and Morley 1994) and overall faunal composition. Vertebrate macrofossils, including KNMWT 47893 , occur primarily as isolated and abraded elements in the lower $200 \mathrm{~m}$ of the $>400 \mathrm{~m}$ section. KNMWT 47893 was recovered during surface collection from an erosional deflation lag at $4^{\circ} 16^{\prime} 46^{\prime \prime} \mathrm{N}, 35^{\circ} 49^{\prime} 02^{\prime \prime} \mathrm{E}$.

Diagnosis - KNM-WT 47893 is here referred to Azhdarchidae on the basis of the following combination of features: a short, high vertebra lacking a pneumatic foramen on the lateral surface of the centrum; a neural arch attached to the cranial half of the centrum.

\section{DESCRIPTION}

KNM-WT 47893 is a caudal cervical vertebra consisting of a fused centrum and neural arch. The vertebra is heavily abraded and lacks cortex over most of its surface, instead revealing the complex meshwork of widely-spaced trabecular bone characteristic of most pterodactyloids (Fig. 2). The centrum is short and low, with overall proportions characteristic of the caudalmost cervical or cranialmost, non-notarial dorsal vertebrae. The centrum is $34.2 \mathrm{~mm}$ long and $29.0 \mathrm{~mm}$ wide at mid-central length. The vertebral height is $36.8 \mathrm{~mm}$ measured from the ventral surface of the centrum to the preserved extent of the neural spine. The centrum is procoelous, dorsoventrally-compressed, and exhibits a distinctly convex condyle on the caudal surface. The reniform condyle extends past the caudal extent of the postzygapophysis (Fig. 2C). The cotyle is moderately concave, does not extend past the cranial extent of the prezygapophysis, and exhibits a slight median hypapophysis at its cranioventral margin (Fig. 2F). The centrum lacks a lateral pneumatic foramen typical of most non-azhdarchid pterodactyloids (Kellner 2003, Averianov 2007; also, see Andres and Ji 2008). There is no evidence of a postexapophysis, indicating that it was either not preserved or that this vertebra is from a more caudal position such that its absence would be expected.

The attachment of the pedicle is restricted to the cranial half of the centrum, resulting in a modest space between the postzygapophysis and the dorsal surface of the centrum (Fig. 2A). This is characteristic of caudal cervical vertebrae ( $\sim \mathrm{C} 8$-C9) in many pterodactyloid taxa. The neural canal is large ( $22 \%$ of centrum height) and round in cross-section when viewed caudally. Poor preservation of the cranial end of the vertebra precludes a direct determination of neural canal size and shape. Pneumatic foramina adjacent to the neural canal are not present on either end of the vertebra. Whereas the ovoid postzygapophyseal facet is oriented at approximately 45 degrees relative to the horizontal, poor preservation prevents any specific determination of prezygapophyseal morphology. A small, craniocaudally-restricted transverse process is preserved at the cranial end of the neural arch on left side only (Fig. 2E); however, incomplete preservation of the cortical surface renders the identification of a distinct diapophyseal facet (as would be 


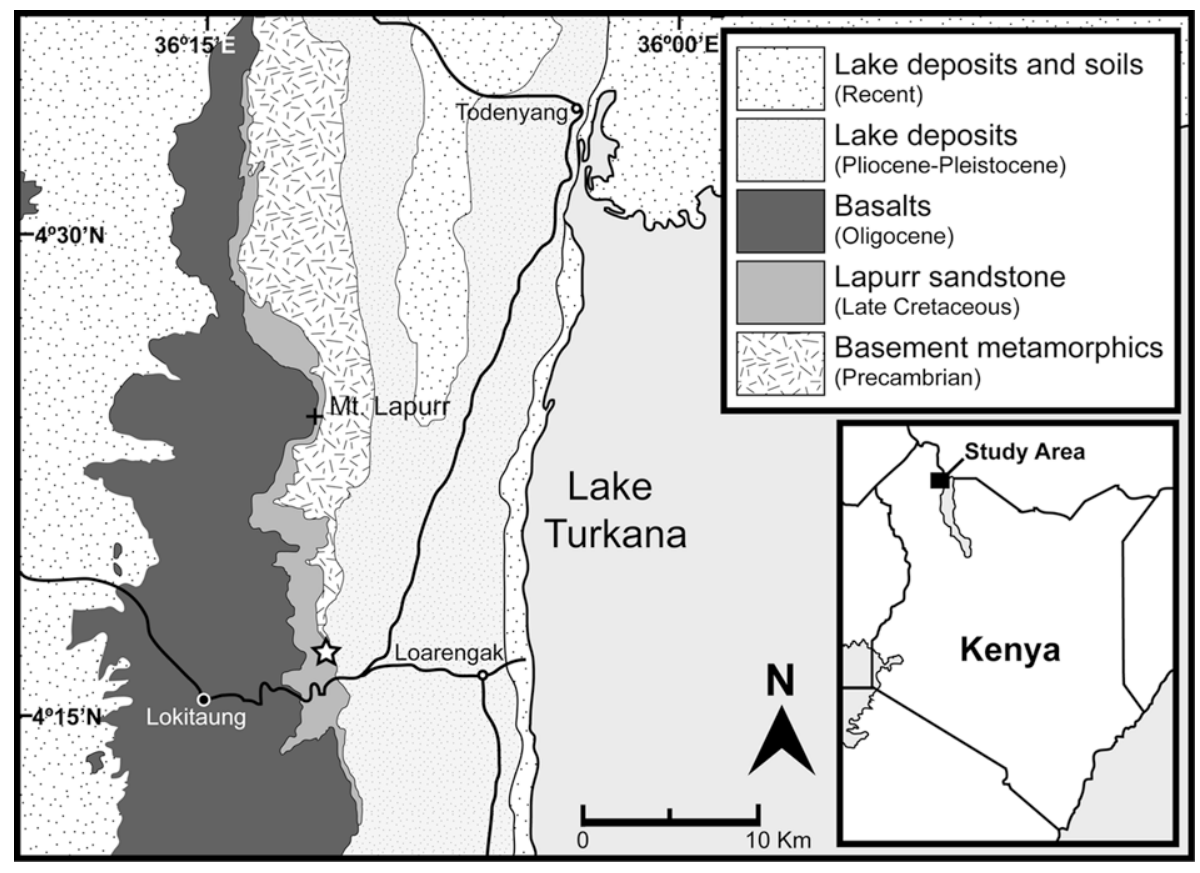

Fig. 1 - Map showing the location of the Lapurr sandstone exposures in northwestern Kenya and the locality (star) from which the pterosaur vertebra here detailed was recovered.

present on a cranial dorsal vertebra) incomplete. The craniocaudally-restricted neural spine slopes caudodorsally, but this may also reflect the state of preservation, and a modest postspinal fossa is present. Due to extreme weathering, it is unclear to what extent the transverse process and neural spine were developed.

\section{DISCUSSION}

The presence of a post-Cenomanian azhdarchid pterosaur in East Africa is consistent with the temporal range of the clade, which minimally spans all of the Late Cretaceous (Unwin 2003, 2006) or from the latest Jurassic through the end of the Cretaceous (Kellner 2003), depending on which classification scheme is used. KNM-WT 47893 compares favorably with an azhdarchid, pre-notarial dorsal vertebra (ZIN PH 54/53 [Paleoherpetological Collection of the Zoological Institute, Russian Academy of Sciences, St. Petersburg, Russia]) recovered from the Late Cretaceous (TuronianConiacian) Tyul'keli locality in Kazakhstan (Averianov 2007). However, KNM-WT 47893 differs in having a centrum that is dorsoventrally compressed relative to ZIN PH 54/53. The general organization of the neural arch relative to the centrum (e.g., a pedicle attached along the cranial half of the centrum) indicates the specimen is positioned within the caudal-most cervical or cranial-most (i.e., pre-notarial) dorsal series (Howse 1986). Moreover, the presence of a reduced hypapophysis further suggests a caudal cervical position for the vertebra. With these characteristics taken together, we have chosen to classify KNM-WT 47893 as a caudal cervical vertebra until additional materials of the Kenyan form are recovered.

The recovery of pterosaur remains from the Late Cretaceous of Kenya is significant for a number of reasons. First, the Afro-Arabian record of pterosaurs is extremely sparse, consisting mostly of isolated bones and teeth from a range of Cretaceous sites in Morocco (Kellner and Mader 1996, 1997, Sigogneau-Russell et al. 1998, Wellnhofer and Buffetaut 1999, Knoll 2000). Notable exceptions among the fragmentary Moroccan discoveries are

(1) the rostral portion of an anhanguerid upper jaw (Mader and Kellner 1999),

(2) an associated series of five cervical vertebrae that have been referred to the Azhdarchidae (Pereda Suberbiola et al. 2003; although see Kellner 2010 


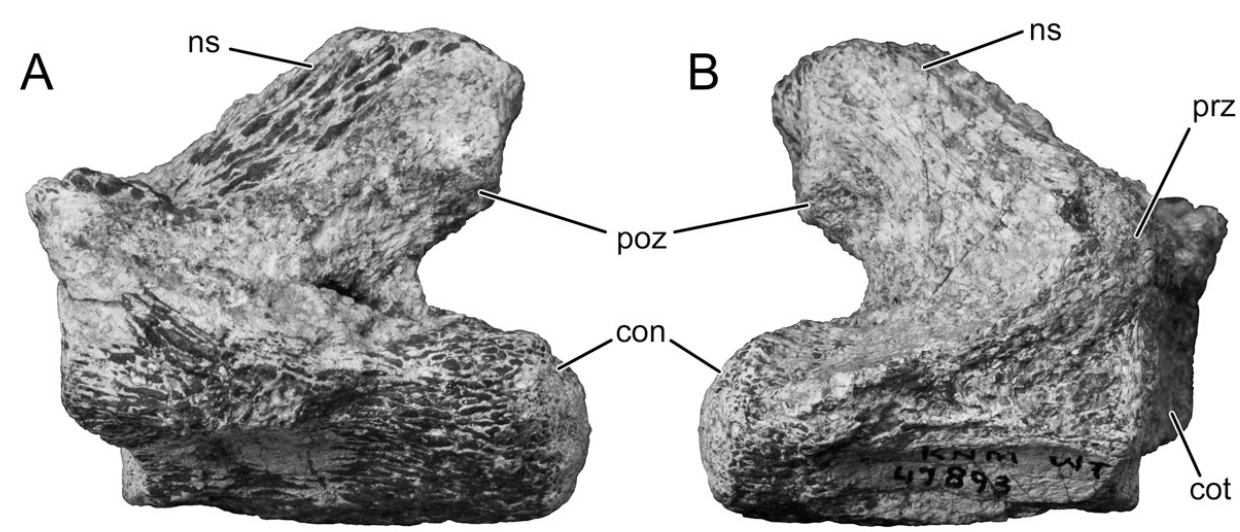

C
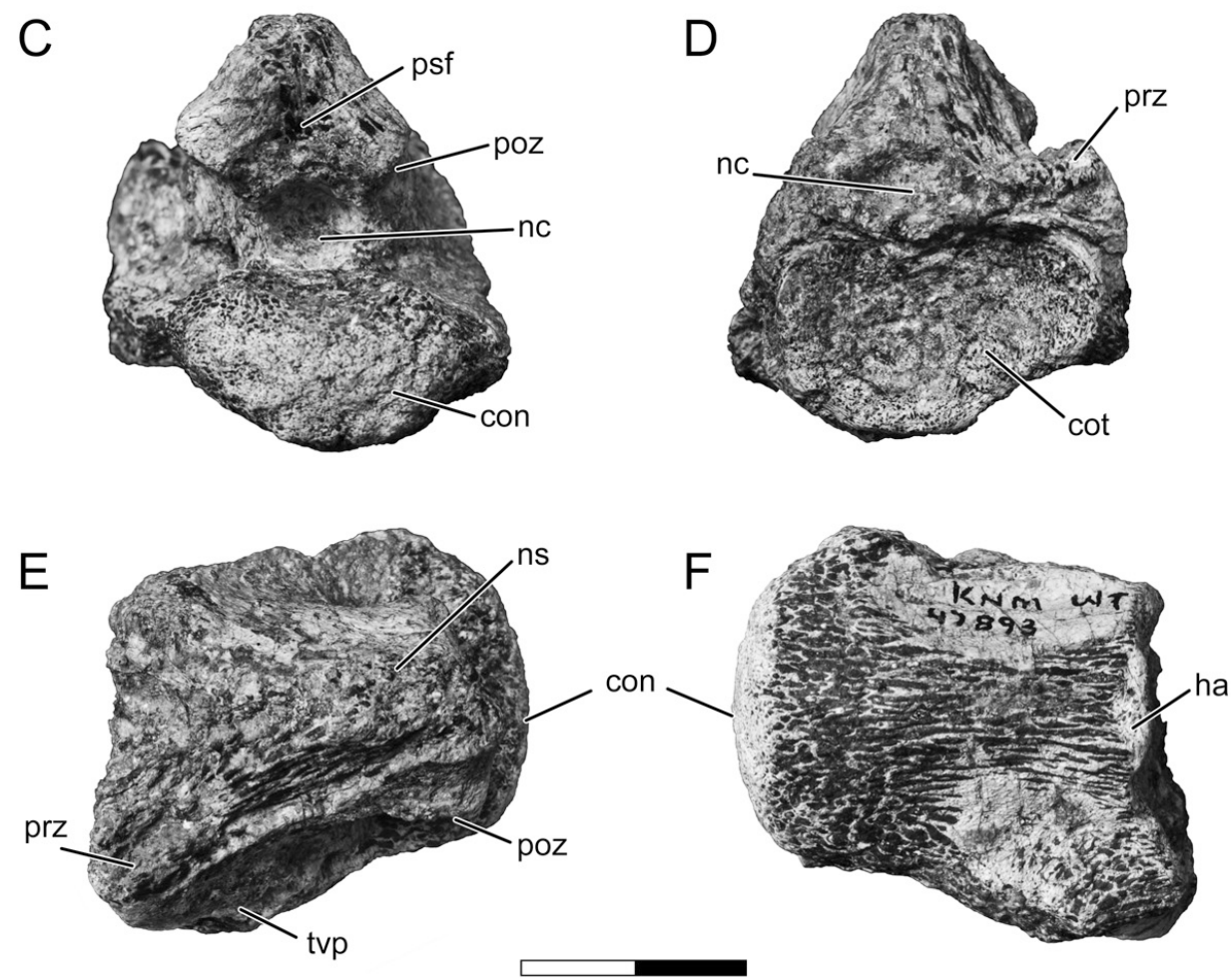

Fig. 2-Caudal cervical vertebra (KNM-WT 47893) of Azhdarchidae indet. in left lateral (A), right lateral (B), caudal (C), cranial (D), dorsal (E), and ventral (F) views. Abbreviations: con, condyle; cot, cotyle; ha, hypapophysis; nc, neural canal; ns, neural spine; poz, postzygapophysis; prz, prezygapophysis; psf, postspinal fossa, tvp, transverse process. Scale bar equals $2.0 \mathrm{~cm}$ in $\mathbf{A}-\mathbf{E}$.

for a comment on the interpretation of this specimen), and

(3) a fused mandibular symphysis recently referred to Azhdarchidae (Ibrahim et al. 2010).

Other occurrences from the African continent include isolated elements from the Upper Jurassic Tendaguru Series in Tanzania (Reck 1931, Galton 1980, Unwin and
Heinrich 1999, Kellner et al. 2007, Costa and Kellner 2009), an ornithocheirid metacarpal from CenomanianTuronian deposits in the Democratic Republic of Congo (Swinton 1948, Monteillet et al. 1982), a cervical vertebra and partial tibia from Campanian-Maastrichtian sequences in Senegal (Monteillet et al. 1982), and an isolated tooth from the Albian of Tunisia (Benton et al. 2000). Other pterosaur material from the then con- 
tiguous portion of what is now westernmost Asia (e.g., Jordan, Israel, etc.) include a pterodactyloid hind limb from the Cenomanian of Israel (Tchernov et al. 1996), cranial endocasts referred to azhdarchids (Lewy et al. 1993), and limited materials of the azhdarchid Arambourgiania from the Maastrichtian of Jordan (Arambourg 1954, Frey and Martill 1996).

\section{CONCLUSION}

The discovery of a new pterydactyloid pterosaur with azhdarchoid affinities from the Late Cretaceous of Kenya, although not unexpected at the continent level, adds a novel datum to a large region of Afro-Arabia. Perhaps most significant is the fact that KNM-WT 47893 was recovered from the fluvial Lapurr sandstone in the Turkana Grits, rather than from marine phosphate units as is typically the case for the vast majority of AfroArabian pterosaurs. Additional fieldwork in the Lapurr sandstone is currently underway and will no doubt continue to add important new data to the extremely sparse Late Cretaceous vertebrate record of Afro-Arabia.

\section{ACKNOWLEDGMENTS}

We would like to thank the scientific, curatorial and preparation staff at the National Museums of Kenya (Nairobi, Kenya) for assistance during the course of this project, specifically, E. Mbua and M. Macharwas. J. Groenke, M. Macharwas, A. Moru, H. Sallam, E. Seiffert, \& others assisted with field research during the 2008 expedition. We also thank the following agencies and institutions for supporting the field and museum research related to this project: US National Science Foundation (EAR-0617561), National Geographic Society (CRE), Ohio University College of Osteopathic Medicine, and Ohio University Office of Research and Sponsored Programs, Turkana Basin Institute.

\section{RESUMO}

Uma vértebra cervical caudal isolada de pterossauro ( póscervical) foi recuperada do Cretáceo Superior do arenito de Lapurr do Oeste de Turkana, noroeste do Quênia. O centro vertebral é curto, largo e comprimido dorsoventralmente. Embora o espécime seja leve como grande parte dos pterossauros, ele é aqui referido a Pterodactyloidea e tentativamente a Azhdarchidae no que diz respeito à ausência de características pneumáti- cas tanto no centro quanto no arco neural. Este representa um dos poucos pterossauros recuperados do conjunto Afro-Arábia, o primeiro pterossauro proveniente do Cretáceo do Leste da África e, significativamente, um espécime que foi recuperado de depósitos fluviais e não do cenário marinho próximo da costa típico da maioria das descobertas de pterossauros.

Palavras-chave: Pterosauria, Pterodactyloidea, África, Quênia, Cretáceo Superior.

\section{REFERENCES}

ANDRES B AND Ji Q. 2008. A new pterosaur from the Liaoning Province of China, the phylogeny of the Pterodactyloidea, and convergence in their cervical vertebrae. Palaeont 51: 453-469.

Arambourg C. 1954. Sur la présence d'un pterosaurien gigantesque dans les phosphates de Jordanie. C R Acad Sci Paris 283: 133-134.

AVERIANov AO. 2007. New records of azhdarchids (Pterosauria, Azhdarchidae) from the Late Cretaceous of Russia, Kazakhstan, and Central Asia. Paleontol J 41: 189-197.

Barrett PM, Butler RJ, Edwards NP AND Milner AR. 2008. Pterosaur distribution in time and space: An atlas. In: Hone DWE And Buffetaut E (Eds), Flugsaurier: Pterosaur papers in honour of Peter Wellnhofer. Zittel B28: 61-107.

Benton MJ, Bouaziz S, Buffetaut E, Martill DM, Ouaja M, Soussi M And TRueman C. 2000. Dinosaurs and other fossil vertebrates from fluvial deposits in the Lower Cretaceous of southern Tunisia. Palaeo Palaeo Palaeo 157: 227-246.

Bosworth W AND MORLEy CK. 1994. Structural and stratigraphic evolution of the Anza Rift, Kenya. Tectonophy 236: 93-115.

Costa FR And Kellner A. 2009. On two pterosaur humeri from the Tendaguru beds (Upper Jurassic, Tanzania). An Acad Bras Cienc 81: 813-818.

Dalla Vecchia FM, Arduini P ANd Kellner AWA. 2001. The first pterosaur from the Cenomanian (Late Cretaceous) Lagerstätten of Lebanon. Cret Res 22: 219-225.

Dingle RV, Siesser WG And NeWton AR. 1983. Mesozoic and Tertiary geology of Southern Africa. Rotterdam: Balkema, $375 \mathrm{p}$.

FREY E AND MARTILl DM. 1996. A reappraisal of Arambourgiania (Pterosauria, Pterodactyloidea): one of the world's largest flying animals. Neues Jahr Geol Paläontol, Abhand 199: 221-247. 
GALTON PM. 1980. Avian-like tibiotarsi of pterodactyloids (Reptilia: Pterosauria) from the Upper Jurassic of East Africa. Palaontol Zeit 54: 331-342.

HAUGHTON SH. 1963. The stratigraphic history of Africa south of the Sahara. Edinburgh: Oliver and Boyd, 365 p.

Howse SCB. 1986. On the cervical vertebrae of the Pterodactyloidea (Reptilia: Archosauria). Zool J Linn Soc 88: 307-328.

IBRAHIM N, UNWIN DM, MARTILL DM, BAIDDER L AND Zouhri S. 2010. A new pterosaur (Pterodactyloidea: Azhdarchidae) from the Upper Cretaceous of Morocco. PLoS ONE 5(5):e10875.

Doi:10.1371/journal.pone.0010875

Kellner AWA. 2003. Pterosaur phylogeny and comments on the evolutionary history of the group. In: BUfFETAUT E AND MAZIN J-M (Eds), Evolution and Palaeobiology of Pterosaurs. London: Geol Soc, London, Spec Pub 217: 105-137.

Kellner AWA. 2010. Comments on the pteranodontidae (Pterosauria, Pteryodactyloidea) with the description of two new species. An Acad Bras Cienc 82: 1063-1084.

Kellner AWA AND MADER BJ. 1996. First report of Pterosauria (Pterodactyloidea, Azhdarchidae) from Cretaceous rocks of Morocco. J Vert Paleont 16(Suppl 3): 45A.

Kellner AWA ANd Mader BJ. 1997. Archosaur teeth from the Cretaceous of Morocco. J Paleont 71: 525-527.

Kellner AWA, Mello AMS AND Ford TL. 2007. A survey of pterosaurs from Africa with the description of a new specimen from Morocco. In: CARVALHO IS ET AL. (Eds), Paleontologia. Cenários de Vida 1: 257-267.

KNOLL F. 2000. Pterosaurs from the Lower Cretaceous (?Berriasian) of Anoual, Morocco. Ann Paleont 86: 157164.

Krause DW, O'CONNOr PM, CURry Rogers K, SAMPSON SD, BUCKLEY GA AND Rogers RR. 2006. Late Cretaceous terrestrial vertebrates from Madagascar: implications for Latin American biogeography. Ann Missouri Bot Gard 93: 178-208.

Lewy ZA, Milner AC And Patterson C. 1993. Remarkarbly preserved natural endocranial casts of pterosaur and fish from the Late Cretaceous of Israel. Geol Sur Israel Cur Res 7: 31-35.

Mader BJ And Kellner AWA. 1999. A new anhanguerid pterosaur from the Cretaceous of Morocco. Bol Mus Nac Geol 45: 1-11.

MAteer JJ ET AL. 1992. Correleation of nonmarine Creta- ceous strata of Africa and the Middle East. Cret Res 13: 273-318.

Monteillet J, Lappartient JR And Taquet P. 1982. Un ptérosaurien géant dans le Crétacé supérieur de Paki (Senegal). C R Acad Sci Paris 295: 409-414.

Morley CK, Bosworth W, Day RA, Lauck R, Bosher R, Stone DM, Wigger St, Wescott WA, Haun D AND Bassett N. 1999. Geology and Geophysics of the Anza Graben. In: MorLEY CK (Ed), Geoscience of Rift Systems - Evolution of East Africa. AAPG Stud Geol 44: 67-90.

O'CONnOr PM, GotTFried MD, SteVEns NJ, Roberts EM, Ngasala S, Kapilima S and Chami R. 2006. A new vertebrate fauna from the Cretaceous Red Sandstone Group, Rukwa Rift Basin, southwestern Tanzania. J Afr Earth Sci 44: 277-288.

Pereda Suberbiola X, Bardet N, Jouve S, IaroChÈne M, Bouya B And Amaghzaz M. 2003. A new azhdarchid pterosaur from the Late Cretaceous phosphates of Morocco. In: Buffetaut E AND MAZIN J-M (Eds), Evolution and Palaeobiology of Pterosaurs. Geol Soc, London, Specl Pub 217: 79-90.

RECK H. 1931. Die deutschostafrikanischen Flugsaurier. Centralbl Mineral Paläeontol B 7: 321-336.

SCOTESE CR. 2001. Atlas of Earth history. PALEOMAP project, Arlington, Texas.

Sertich JJW, Sampson SD, Loewen MA, Gathogo P, BROWN FH AND MANTHI FK. 2005. Dinosaurs of Kenya's rift: Fossil preservation in the Lubur Sandstone of northern Kenya. J Vert Paleont 26(Suppl 3): 114A.

Sertich JJW, SAmpson SD, Loewen MA, Getty MA AND MANTHI FK. 2006. Rift valley dinosaurs: a new Late Cretaceous vertebrate fauna from Kenya. J Vert Paleont 26(Suppl 3): 124A.

Sigogneau-Russell D, Evans SE, Levine JF AND RUSSELl DA. 1998. The Early Cretaceous microvertebrate locality of Anoual, Morocco: a glimpse at the small vertebrate assemblages of Africa. In: LUCAS SG ET AL. (Eds), Lower and middle Cretaceous terrestrial ecosystems, New Mexico: New Mex Mus Nat Hist Sci Bul 14: 177-181.

SWINTON WE. 1948. A Cretaceous pterosaur from the Belgian Congo. Bulletin de la Société Belge de Géologie, Paleont Hydrol 47: 234-238.

TChernov E, Polcyn MJ And JACOBS LL. 1996. Snakes with legs: The Cenomanian fauna of 'Ein Yabrud, Israel. J Vert Paleont 16(Suppl 3): 68A. 
Tiercelin J-J, Potdevin J-L, Morley CK, TAlbot MR, Bellon H, Rio A, Le Gall B and Vétel W. 2004. Hydrocarbon potential of the Meso-Cenozoic Turkana Depression, northern Kenya. I. Reservoirs: depositional environments, diagenetic characteristics, and source rock-reservoir relationships. Mar Pet Geol 21: 41-62.

UNWIN DM. 2003. On the phylogeny and evolutionary history of pterosaurs. In: BuffetAut E AND MAZIN J-M (Eds), Evolution and Palaeobiology of Pterosaurs, London: Geol Soc, London, Spec Pub, p. 139-190.

UnwIN DM. 2006. The pterosaurs from deep time. New York: PI Press, 347 p.
UNWIN DM AND HEINRICH WD. 1999. On a pterosaur jaw from the Upper Jurassic of Tendaguru (Tanzania). Mitt Mus Nat Ber 2: 121-134.

Wellnhofer P And Buffetaut E. 1999. Pterosaur remains from the Cretaceous of Morocco. Palaontol Zeit 73: $133-142$.

Winn RD, Steinmetz JC AND KeREKGyarto WL. 1993. Stratigraphy and rifting history of the MesozoicCenozoic Anza Rift, Kenya. Amer Assoc Pet Geol Bul 77: 1989-2005. 